\title{
International Performance Evaluation - Taking ZTE Corporation as an Example
}

\author{
Jie Peng ${ }^{\mathrm{a},}{ }^{*}$, Qingqing Wu \\ School of Nanjing University of Science and Technology, Nanjing 210000, China \\ a1509960732@qq.com
}

Keywords: multinational, International performance, ZTE, Suggest.

\begin{abstract}
With the rapid development of communications technology and the continuous acceleration of the flow of international commodities, capital, technology and talents, multinationnal companies have emerged and international competition has become increasingly fierce. In this paper, combining the specificity of multinational corporations, this article studies the international performance of ZTE from the perspectives of financial indicators, strategic perspectives, employee performance, equity incentives, etc., in order to provide relevant recommendations for improving the performance evaluation of multinational corporations, and to promote the Sustainable development.
\end{abstract}

\section{Introduction}

With the advancement of world economy and trade, the links between countries have been gradually strengthened, and the degree of interdependence continues to increase, and investment among countries has also become increasingly frequent. For China, its economic strength and international influence continue to increase, and it is inspired by the country's "going out" strategy. In recent years, more and more Chinese multinational companies have begun to go abroad, establish branches overseas, and even invest in direct investment. Plant. However, in this process, due to the lack of relevant experience in cross-border management and a clear localization strategy, many Chinese-funded enterprises have been declining their overseas expansion operations. Therefore, this article will use ZTE as an example to study the international performance of transnational corporations from the perspective of financial indicators and non-financial indicators, and provide corresponding suggestions for improving the performance evaluation of transnational corporations to promote the sustainable development of corporations.

\section{Case analysis}

\subsection{Basic Situation of the Company.}

Founded in 1985, ZTE Corporation is the largest listed telecommunications equipment company in China. It is represented by Hour Weighing and successfully listed on the Shenzhen Stock Exchange and the Hong Kong Stock Exchange. In the development of several decades, the company has grown year by year and is the leading company among the listed companies in the industry. ZTE Corporation's pursuit of excellence in innovation has led to the establishment of $18 \mathrm{R} \& \mathrm{D}$ centers in the world with huge scientific research costs, which are located in different countries around the world. These R \& D institutions include nearly 30,000 R \& D personnel at home and abroad. In 2007, the company was selected as "affecting China's Top Ten Listed Companies" and its internationalization strategy has achieved a breakthrough. In the same year, the company's main business income in foreign countries accounted for more than $60 \%$ of its revenue. It is a truly transnational company.

\subsection{Evaluation of International Financial Performance.}

The multinational company performance evaluation system uses strategic business units or budget units as evaluation objects, provides support information for the formulation of multinational companies' strategies, and provides control information for the effective implementation of strategies. Its core part is the design of the performance evaluation index system. 
For ZTE, when conducting international performance evaluation, it is necessary to evaluate not only its financial indicators, but also a certain amount of non-financial indicators. Non-financial indicators are a series of qualitative indicators developed from the perspective of strategic management. For example, the company will evaluate the company's strategy, expatriates, and customers' dimensions.

\subsubsection{Financial Indicators.}

In the analysis and evaluation of financial indicators for ZTE, this article mainly uses the ratio analysis method, and selects data from the past five years to analyze from the perspectives of solvency, profitability, and operational capabilities.

(i) Analysis of solvency

Table 1. Debt ratio analysis table

\begin{tabular}{|c|c|c|c|c|c|c|}
\hline & & 2013 & 2014 & 2015 & 2016 & 2017 \\
\hline \multirow{3}{*}{$\begin{array}{c}\text { short } \\
\text { term }\end{array}$} & Current ratio & 1.13 & 1.25 & 1.41 & 0.95 & 1.24 \\
\cline { 2 - 7 } & Quick ratio & 0.58 & 0.66 & 0.79 & 0.64 & 0.66 \\
\cline { 2 - 7 } & Cash ratio & 0.29 & 0.27 & 0.41 & 0.35 & 0.38 \\
\cline { 2 - 7 } & Operating cash flow ratio & 0.04 & 0.04 & 0.11 & 0.06 & 0.08 \\
\hline \multirow{2}{*}{ long-term } & Assets and liabilities & 1.31 & 1.33 & 1.56 & 1.41 & 1.46 \\
\cline { 2 - 7 } & Long-term debt ratio & 0.40 & 0.35 & 0.19 & 0.18 & 0.19 \\
\hline
\end{tabular}

From Table 1, it can be seen that Although it has gradually become stable in the last two years, It has recovered but has completely deviated from the normal requirement that the current ratio is 2 and the quick ratio is 1 , indicating that the net cash flow from ZTE's operating activities has been difficult to guarantee the repayment of current liabilities.

(ii) Analysis of profitability

Table 2. Profitability Analysis Table unit:100 million

\begin{tabular}{|c|c|c|c|c|c|}
\hline & 2013 & 2014 & 2015 & 2016 & 2017 \\
\hline Total assets & 1000.79 & 1062.14 & 1208.94 & 1416.41 & 1439.62 \\
\hline Operating income & 752.30 & 814.70 & 1001.90 & 1012.30 & 1088.20 \\
\hline $\begin{array}{c}\text { Domestic } \\
\text { operating income }\end{array}$ & 356.30 & 405.80 & 531.10 & 585.50 & 619.60 \\
\hline International operating income & 396.00 & 408.90 & 470.80 & 426.80 & 468.60 \\
\hline Gross profit & 221.08 & 257.11 & 310.86 & 311.33 & 338.09 \\
\hline Sales margin (\%) & 1.91 & 3.35 & 3.73 & -1.39 & 4.95 \\
\hline Total asset net rate & 1.38 & 2.64 & 3.29 & -1.07 & 3.77 \\
\hline
\end{tabular}

From Table 2, it can be seen that ZTE's overseas expansion activities in recent years have made the overall profit increase. With overseas expansion, the proportion of operating revenue realized by ZTE International is also rising. Based on the survey, it can be known that ZTE has caused financial difficulties due to global expansion in 2012, and domestic and foreign expansion based on low-cost strategies is clearly not suitable for the development of ZTE. The adjustment of the strategy needs to be put on the agenda, and exploring the core competitive advantage of the company is the only way out for the future development of ZTE.

\subsubsection{Strategic perspective.}

Within ZTE, there is a general consensus of "three decades", which is the history of company development. The first phase (1985 1994) was mainly ZTE's clear development model of independent research and development in the field of communication manufacturing, and initially entered the stage of rural communication market; the second phase (1995 2004) was established by ZTE in the domestic market. The status of the leading enterprise and the stage for laying the foundation of a world-class outstanding enterprise. The third phase (2005-2012) is a crucial period for ZTE to fully compete in the global market and grow into an international first-class communication manufacturer. Since the financial situation of ZTE began to deteriorate in 2012, the company proceeded with strategic adjustment. In these three stages, ZTE has always adopted a low-cost strategy at the operating level. At the company level, as the company grows and develops, it 
adopts a diversification strategy. At the highest level, ZTE adheres to the strategy of globalization. In order to realize the globalization strategy and avoid the frontal battle with transnational communication vendors as much as possible, we adopted the "easy-to-follow" approach, using low-cost advantages to start with developing countries in China's periphery and gradually expand to Africa and Latin America. Infiltrate into Eastern Europe, Western Europe, and the United States. ZTE Corporation has established representative offices in more than 50 countries in more than ten years of international expansion. The business covers more than 70 countries including Asia, Africa and Latin America, and more than 10 types of equipment are operating in over 30 countries and regions.

(iii) Analysis of operational capacity

Table 3. Operational performance analysis table

\begin{tabular}{|c|c|c|c|c|c|}
\hline & 2013 & 2014 & 2015 & 2016 & 2017 \\
\hline Accounts receivable turnover (times) & 3.46 & 3.50 & 3.98 & 3.95 & 4.32 \\
\hline Accounts receivable turnover days (days) & 103.98 & 102.84 & 90.56 & 91.13 & 83.28 \\
\hline Inventory turnover days (days) & 80.90 & 103.39 & 102.44 & 119.51 & 127.30 \\
\hline Inventory turnover rate (times) & 4.45 & 3.48 & 3.51 & 3.01 & 2.83 \\
\hline Fixed asset turnover (times) & 10.34 & 11.01 & 13.30 & 13.25 & 13.33 \\
\hline Total asset turnover (times) & 0.73 & 0.79 & 0.88 & 0.77 & 0.76 \\
\hline Total assets turnover days (days) & 496.48 & 455.75 & 408.02 & 466.81 & 472.44 \\
\hline Turnover of liquid assets (times) & 0.95 & 1.03 & 1.13 & 0.97 & 0.98 \\
\hline Current assets turnover days (days) & 380.47 & 350.47 & 318.95 & 370.10 & 365.71 \\
\hline $\begin{array}{c}\text { Turnover days of inventory and accounts receivable } \\
\text { in total assets turnover days (\%) }\end{array}$ & $37 \%$ & $45 \%$ & $47 \%$ & $45 \%$ & $45 \%$ \\
\hline
\end{tabular}

From Table 3, It shows that there is still certain risk in ZTE's inventory management. Once the sales of products are hindered, the reduction in sales revenue is more significant than the decrease in business cycle, and the total cash withdrawal rate is drastically reduced. In addition, in the past few years, ZTE has almost continuously expanded and seized the market. It lacks the focus on product $\mathrm{R} \& \mathrm{D}$ and production, and it has been difficult to retain the residents only because of its price advantage. Poor sales of products and high inventory levels are inevitable trends.

However, with the development of science and technology, communication technology is upgrading faster and faster. Especially in 2012, the global economic slowdown, the global communications industry as a whole is in the doldrums, operators are faced with the risk of becoming increasingly pipelined, coupled with the decline in the traditional business profitability ZTE welcomes its first winter since its listing and has an operating profit of -2604621000 yuan. Therefore, in 2013, ZTE focused on strategic adjustment.

In 2013, investment in equipment in the global telecom industry continued to grow slowly. ZTE has established the core business ideas of "breakthrough and intensive innovation". However, due to the lack of vision to invest in intelligent terminals, it is still dominated by the operating network, which is affected by the decline in operating income of the terminal products, which led to a $10.6 \%$ drop in overall operating income compared to 2012. In 2014, ZTE continued to adhere to the strategy of a large population and mainstream operators around the world. While striving for stable operations and high quality growth, ZTE continued to enhance its overall competitiveness, and it has established all-round cooperation relationships with mainstream operators worldwide. In addition, more emphasis was placed on strengthening the management and control of financial costs and reducing the impact of exchange rate fluctuations on the Group's operations, and the overall financial expenses have decreased significantly. In 2015, ZTE proposed the "Restructuring of the Times as an Opportunity, Information Creation Value," focusing on the three mainstream markets of "operators, government, enterprises and consumers" and focusing on "emerging areas" such as smart voice and smart wireless charging. Distributed grid-connected power generation, big data platforms and applications, connected finance, mobile payments, etc., through technology and business model innovation, to achieve profitability model breakthrough. In 2016, both operating income and operating profit have increased by a certain margin. This is mainly due to the fact that during the year, ZTE Corporation exercised flexible control over foreign exchange risk exposure, achieved greater 
exchange gains, and implemented a structure of interest-bearing liabilities. In the just-released 2017 annual report, ZTE's overseas revenue for the year 2017 totaled 46.9 billion, which exceeded its historical high point overseas. The RMB 46.8 billion in 2011 was once seen as a milestone after 2012. ZTE looks to 2018, and with the rapid growth of network traffic, it will face new opportunities for development. On April 16, 2018, the U.S. Department of Commerce formally issued sanctions, announcing that it would prohibit U.S. companies from launching any business with ZTE within seven years. On April 17, ZTE's stocks listed on the Shenzhen and Hong Kong stock exchanges were suspended. Although this incident paid ZTE a fine of US\$1 billion and another 400 million U.S. dollars went to the third-party custody of such a settlement agreement, this incident undoubtedly sounded the alarm for domestic high-tech companies and should be more resolutely invested in core technologies. R \& D and breakthrough. ZTE, after experiencing painstakingly, will continue to bravely advance and continue to make strategic adjustments to optimize corporate performance and promote sustainable development.

\subsubsection{Outpost performance management.}

In the performance management of expatriate personnel of transnational corporations, on the one hand, expatriates have their own development aspirations and requirements during the expatriate assignment, that is, there are plans for the expatriate's own career goals. On the other hand, in the case of transnational corporations, they should pass training. , incentives, promotions and other means to help expatriates achieve their career goals. However, the desire of transnational corporations is to achieve the strategic goals of globalization and to maximize their profits. Therefore, there are often contradictions in these two aspects. To solve this contradiction, multinational corporations should guide the career design of expatriates and try to be consistent with the corporate development strategy. In addition, conduct corresponding performance evaluation on the target, improve the enthusiasm and creativity of expatriates, reduce the differences between the two, and promote the common development of the company and its employees.

(i) Current Human Resources Status of ZTE Corporation

According to the 2017 Annual Report, you can get the following table:

Table 4. According to the professional composition of the classification

\begin{tabular}{|c|c|c|}
\hline category & Number of employees (person) & $\begin{array}{c}\text { About the proportion of the total } \\
\text { number of people }\end{array}$ \\
\hline R \& D personnel & 28,942 & $38.70 \%$ \\
\hline Marketing staff & 11,375 & $15.20 \%$ \\
\hline customer service & 12,172 & $16.30 \%$ \\
\hline Production staff & 16,851 & $22.50 \%$ \\
\hline Financial officer & 871 & $1.20 \%$ \\
\hline Administrative staff & 4,562 & $6.10 \%$ \\
\hline total & 74,773 & $100.00 \%$ \\
\hline
\end{tabular}

Table 5. Academic qualifications

\begin{tabular}{|c|c|c|}
\hline Education & Number of employees (person) & About the proportion of the total number of people \\
\hline doctor & 416 & $0.60 \%$ \\
\hline master & 22,903 & $30.60 \%$ \\
\hline Bachelor & 29,451 & $39.40 \%$ \\
\hline other & 22,003 & $29.40 \%$ \\
\hline total & 74,773 & $100 \%$ \\
\hline
\end{tabular}

According to the above chart, by the end of 2017, the number of employees in the company has reached 74,773 , of which 28,942 are $R \& D$ personnel, accounting for $38.70 \%$. The number of masters and doctors or above is 23,319 , accounting for $31.20 \%$. As can be seen from the company's employee structure, the proportion of high-quality core R\&D personnel should not be underestimated. This is in line with the characteristics of ZTE Corporation being a high-tech technology industry. With the 
continuous expansion of ZTE's international business, the number of ZTE service countries and regions has gradually increased, and expatriates have also shown steady growth.

They mainly focus on skills training under cultural conflict and first, cultural sensitivity training. Second, technical and managerial skills training, In the face of cultural conflicts, expatriates may need comprehensive technical or managerial skills to promote or interpret the company's product or business management concepts. Third, organization and coordination. Compared with domestic fixed jobs, expatriates are faced with new groups and need to organize their own work teams separately. Fourth, the training of cultural common sense from the east to the country or the mother country. Fifth, develop innovative capabilities. In response, ZTE also made corresponding measures in employee training. ZTE has always emphasized and implemented the "people-oriented" corporate culture, building a learning organization. Expatriate personnel develop effective compensation and benefit plans, and consider the assignment of expatriates. Through the analysis of the long-term cumulative assessment results, the employees' potential abilities are discovered and suitable career planning is formulated for them.

\subsection{4 equity incentives}

ZTE conducted two equity incentive plans in 2006 and 2013 respectively. The implementation of the first equity incentive plan in 2006 was mainly aimed at expanding the overseas 3G market and increasing the operating performance of ZTE Corporation; retaining the core talent for the enterprise and establishing a sound salary system. and then implemented the second equity incentive plan. A comparative analysis of the changes in the two equity incentive $R \& D$ personnel is now presented.

Table 6. Changes in the first equity incentive R\&D personnel

\begin{tabular}{|c|c|c|c|c|c|}
\hline & 2006 & 2007 & 2008 & 2009 & 2010 \\
\hline R\&D staff & 13600 & 16940 & 20750 & 23544 & 27941 \\
\hline total people & 39266 & 48261 & 61350 & 70345 & 85232 \\
\hline Accounting & $34.64 \%$ & $35.10 \%$ & $33.82 \%$ & $33.47 \%$ & $32.78 \%$ \\
\hline
\end{tabular}

The company's total number of employees has gradually increased. After the equity incentive plan was announced in 2006, the number of employees has increased dramatically, and the corresponding number of $R \& D$ personnel has also increased dramatically, but from the proportion From the perspective of the implementation of the first equity incentive plan, the ratio of $R \& D$ personnel increased in 2007 and began to decline gradually in 2008. This indicates that the first time the equity incentive plan had a significant effect on the purpose of retaining core personnel, but Persistence is not strong.

Table 7. The Second Equity Incentive R\&D Staff Changes

\begin{tabular}{|c|c|c|c|c|c|}
\hline & 2011 & 2012 & 2013 & 2014 & 2015 \\
\hline R\&D staff & 30187 & 29764 & 25874 & 27101 & 31703 \\
\hline total people & 89768 & 78402 & 69093 & 75609 & 84622 \\
\hline Accounting & $33.62 \%$ & $37.95 \%$ & $37.96 \%$ & $35.84 \%$ & $37.50 \%$ \\
\hline
\end{tabular}

With the gradual expansion of production scale, the total number of employees of ZTE reached the highest value in 2011. Due to the declining business performance of its enterprises in 2012 and 2013, ZTE Corporation may use layoffs to reduce costs and achieve cost reduction. The series of measures has led to a decrease in the total number of employees. After the implementation of the second equity incentive plan in 2013, the total number of employees has rebounded in 2014 and 2015. In terms of the proportion of R\&D personnel, although the total number of people in 2014 has decreased, the number of R\&D personnel has risen again in 2015. Explain that the second equity incentive plan has a positive effect.

ZTE's announcement clearly stated that the target of equity incentives is mainly the company's management layer, core technical backbone, and employees who have made important contributions to the company's development. After the implementation of the two-stage equity incentive plan, ZTE Corporation has granted a certain proportion of equity to the incentive objects, effectively improving the management efficiency of the management, and reducing the agency costs between the shareholders and the management to some extent. The assessment conditions directly link the specific 
indicators in the company's financial statements with the remuneration of the management, and use the accounting performance indicators as the basis for management incentives, thereby prompting the management to make decisions that are conducive to the growth of the company's financial performance. It has prevented the company's shareholders from losing their interests and is conducive to the operation of further incentive mechanisms in the future.

Another positive response of ZTE's implementation of equity incentives is to retain talent, reduce the turnover rate of employees, and stabilize the workforce Judging from the performance of ZTE's implementation of the equity incentive plan, the general employee turnover rate before the implementation was $10 \%$, and the turnover rate of core employees was $4 \%$. After the implementation of equity incentives, the turnover rate of core employees dropped to $1 \%$. The main reason is that senior management is a scarce resource for society. Enterprises must use this resource to pay them high salaries and pay higher costs. In contrast, companies use equity incentives to link senior management with companies through equity. If these executives leave during the duration of the options, they will lose their remaining unexercised rights, which is bound to increase. The opportunity cost of leaving the management personnel. Therefore, this method is a way to stabilize employees. It not only retains talent for the company, but also reduces the company's human resource costs.

\section{Conclusion}

This article analyzes ZTE's international performance and analyzes it from different perspectives. It can intuitively feel the difference between international performance evaluation and traditional performance evaluation. Although ZTE's performance management is generally in a better position, there are still areas where it is worth further improvement, such as poor communication channels for performance management among subsidiaries, large cultural differences, and so on. therefore, to achieve the sustainable development of enterprises, we must increase the control and necessary investment in this area, including professional performance management personnel, create a high-performance corporate culture, a sound supporting system, etc. Improve the weaknesses in performance management and better promote the sustainable development of the company.

\section{References}

[1] Jie Qianying Analysis and Evaluation of Financial Statements of ZTE Corporation [J] China Information Technology in Management, 2016,19 (24) :28-29.

[2] Tang Hong. An Analysis of the Effects of Capital Structure of Chinese Multinational Companies on Their Performance [d]. Huazhong University of Science and Technology, 2013.

[3] Li Bai, Research Performance Evaluation of Multinational Companies [J] Cooperative Economy and Technology, 2011 (12): 51-52.

[4] Guo Yuchun, Performance Evaluation of Multinational Corporations [J] Business Research, 2007 (01) :70-73. 